\title{
Green Corridor Development as an Approach for Environmental Sustainability in Jordan
}

\author{
Abdelfattah Al Masri1 ${ }^{1}$ Özge Özden ${ }^{2}$, Can Kara ${ }^{1}$
}

\begin{abstract}
The expansion of urban areas leads the loss of green spaces causing many environmental and economic problems. The infrastructure has been carried to the rural areas to deal with the needs of populations, reducing the green vegetation. This isolates one habitat area from other habitats and increases the fragmentation. A green corridor can connect fragmented habitats. Thus, this research aims to analyze and provide a green corridor in four different cities of Jordan. Through study some case studies, review of articles, researches, data collection, GIS, observations and maps derived from Jordanian ministries were used for the analysis of a green corridor in four cities in the northwest of Jordan. This research provides a comprehensive planning of the biogeographically areas, ecotourism sites and variety of vegetation in the protected areas of namely, Ajloun Forest Reserve and Dibben Forest Reserve, to link them in the biodiversity and conservation regions of the Al-Salt and north Amman, after identifying these diverse areas of vegetation cover and wildlife in each governorate. In addition, the research discusses ecological, environmental and economic effects of applying a green corridor as a sustainable city approach in Jordan. In other words, the purpose of this study is to suggest a sustainable proposal by analyzing green area zones and green corridor axes to improve the nature and the environment in Jordan. This proposal adapts urban areas with the establishment of green corridor connecting conservation areas in Jerash and Ajloun to Al-Salt and north of Amman. Such a green corridor can lead an increase of local and international tourism which may improve the economic strength and can increase the job opportunities for citizens to live in a more ecological urban environment.
\end{abstract}

Keywords: Environmental sustainability; green corridor; connectivity; planning; Jordan

\section{Introduction}

The idea of green corridor design emerged in the 1980s. The importance of the Green Corridor has become increasingly important in the protection of nature. The basic rule of the Green Corridor is as follows: Getting connectivity of one habitat fragment from other areas of habitat which allows an exchange of individuals between natural living elements (Curci \& Durdic, 2013). Conservation area is defined as a territory or place of nature isolated and located away from human activities for the protection of animals and plants (Arpentieva, 2018). The conservation theory of nature supports the connection between isolated areas and increases the level of biodiversity in each separated region. The use of the green corridor was from nature requirements in the wildlife before more than eighty years this provided to enhance the natural biodiversity (Horskins et al., 2005). With urbanization growth and urban development, cities are becoming an essential home for human; the city has become more influential than man's

| ${ }^{1}$ Department of Architecture, Faculty of Architecture, University of Near East, Nicosia, North Cyprus. ${ }^{2}$ Department of Landscape Architecture, Faculty of Architecture, University of Near East, Nicosia, North Cyprus. 
work on Earth. Because of this human population growth, wildlife and natural resources have been threatened worldwide. Urban growth has changed the habitat of mosaics; this contributes to loss of biodiversity and vegetation within the city, and in green areas. The biodiversity system shows an important role in supporting human activities, natural life; enhance air quality and ecotourism benefits (Ratih \& Febrianto, 2016). Jordan, as a Mediterranean country, where the desert represents the largest percentage of its area $(\sim 70 \%)$, starts giving more concentration to nature reserves. This is clear through the increasing concentration in establishing more and more protected areas. Moreover, whilst spatial planning using GIS had been used in many natural applications in Jordan (Haddad et al., 2013) cities in Jordan have experienced a population decrease in recent years. Urbanization is very high in Jordan. In 1998, most of the population in Jordan was living in developed areas. On the other hand, that will expand in the future, which may probably reach more than $80 \%$ of the total population by the year 2010 to provide with the requirements of populations (Jaber \& Probert, 2001). Tukan (1995) describes the center of the cities in Jordan expands as large villages, usually the urbanization in the center of the city, affected by several social, political and economic factors. Toukan is a Jordanian architect describes the growth and urban development in Amman due to political and economic factors in the region lead to an explosion in the population density.

This paper discussed and evaluated the green areas, zones in four cities in Jordan namely: Jarash, Ajloun, Al-Salt, and northern Amman, results will enable us to obtain a green corridor design linking the four cities and improving the expected environmental image of the future by the using GIS. Green corridors that provide habitat connections and movement routes through the urban environment, where these are linked to their wider surroundings, landscaping, tree and shrub planting and habitats such as woodlands, wetlands, heathland, and grassland, that can provide ecotourism benefits, healthy living spaces, improve fragmented sites of biodiversity. By identifying existing locations of habitats and linking them to existing green open spaces along a green corridor is important to understand the integrity of the green infrastructure network.

\section{Background and Research Problem}

The scheme for sustainable urban development in Jordan is currently being considered through a national comprehensive plan for Jordan Behind the National Green Growth Plan, is an obvious vision for Jordan as a country with an expanding and sustainable economy that creates jobs, provides income for citizens, and is resilient to obstacles and instability in the region. A country of economic opportunity for citizens that provides decent work and living requirements based on an environmentally sustainable economic growth model. Most Jordanian cities are exposing from urbanization growth which is due to increase immigration from neighboring countries as well as the urban migration patterns of citizens from outlying rural regions. Urban expansion in all directions has resulted in the destruction of vegetation and natural resources (Saleh \& Alrawashdeh, 2007). One of the main problems for most urbanized 
countries and regions is the conversion of biodiversity into developed land covers, which is a direct result of urbanization (Makhamreh \& Almanaseyha, 2011).

The research problem is presented a growth of the population and urban extension towards the vegetation has resulted in negative impacts with random directions on the natural environment which has appeared in fragmentation for greenery systems, reducing the patches area, losing the verity of biodiversity, isolated area of habitat that decreases species of biodiversity. Royal Society for the conservation of Nature has managed the reserves (protected areas) where the natural biodiversity, they have mentioned in this research in the north of study area namely, Ajloun Forest Reserve and Dibben Forest Reserve. When The Municipality of each district cuts trees to create new service roads that reduce the humble awareness of citizens has appeared in hunting and cutting trees to heat the houses and cutting of trees for construct new commercial buildings.

In the south of study area has mentioned two rich areas of nature diversity (Zay forest and Alhummar forest) especially with the variety of shrubs and trees as an attractive place for local citizens in spring and summer. Local Citizens throw the trash after leaving the place and finishing their trip that Destructs of the wild and natural life. The non-connectivity and local communities between the rich biodiversity areas south and the protected areas north together that led to the disappearance of wildlife. All these factors have negatively impacted the natural environment life. The enormous urban areas have also expanded in loss of green spaces, minimization Open spaces and large separations between wetlands and the habitat of wildlife. Moreover, that isolates one habitat fragments from other areas of habitat. The infrastructure has been moved to the rural areas that were reducing the green vegetation to deal with the needs of populations.

The type of fuel used in Jordan and the industries has led to the rise of environmental pollution, which claims to be an awareness idea to reduce this situation. Jordan is a country rich in natural, cultural and historical and resources, with the increase in population was observed decrease in vegetation types, especially in the study area, which includes five major cities in Jordan, extending from the far north to the center of the capital Amman.

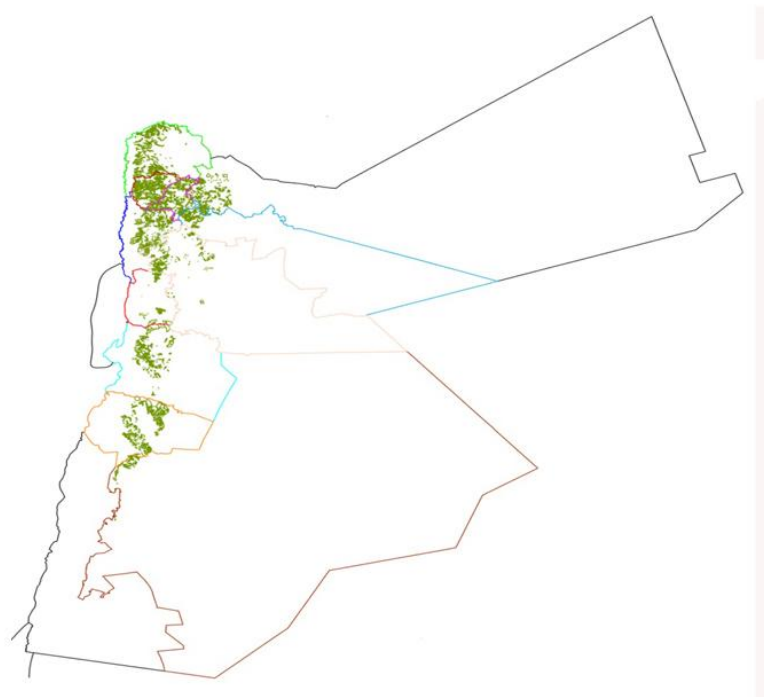

Figure 1: Tha Hashemite Kingdome of Jordan, Forest zoning in Jordan $M O A$, 2018). 
According to Figure 1, by distribution the forest zoning in Jordan the rich diversity in the northwest, geography and land cover hinder connectivity of green areas, there are isolated habitat patches along the study area. Our research provides a connective green corridor proposal to enhance and improve the quality of urban life. Urbanization growth is playing as the main factor in the fragmentation of green areas, especially toward the rural areas to serve the population requirements.

This study is based on urban observations in the study areas that will lead to the identification of environmental problems facing these four cities (see Figure 2). The analyzing and collecting the information that helps us to provide the results that will enable us to obtain a green corridor design linking the four cities and improving the expected environmental image of the future by the using GIS program.

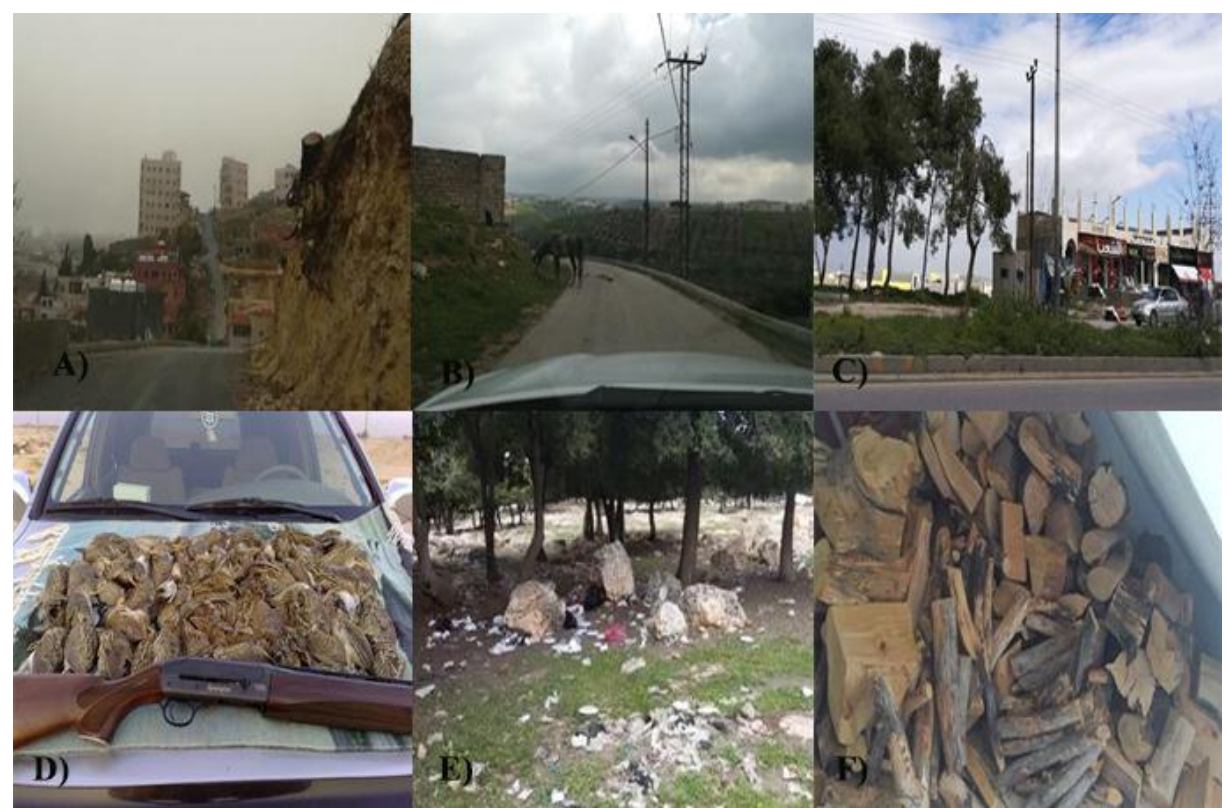

Figure 2: A) Cutting trees to create and expand new roads; B) Run over the animals on the roads; C) Cutting of trees to construct new commercial buildings; D) Hunting the birds; E) Throwing the trash; F) Cutting trees to heat the bouses (Author, 2018)

\section{Literature Review}

\subsection{What is a Green Corridor?}

Green corridors can be defined as approach to provide the continuity of urban green areas. There are many definitions that landscape designers describe as follows: Ndubisi et al. (1995) `s definition is "networks of linked landscape elements that provide ecological, recreational, and cultural benefits to the community ". Walker \& Craighead (1997), describe green corridor as "avenues along which wide-ranging animals can travel, plants can propagate, genetic interchange can occur, populations can move in response to environmental changes and natural disasters, and threatened species can be replenished from other areas ". According to Hilty et al. (2006), another definition is 
"Corridor is any space, usually linear in shape that improves the ability of organisms to move among patches of their habitat". The green corridor is a link between vegetation and plants to provide and support the wildlife required elements, where we have observed the improvement of the environment along the green corridor.

\subsection{Potential Benefits of the Green Corridor}

Green corridor as a sustainable environment corridor enhances a high-quality life by providing the inhabitants a sense of the spaces by the interesting in nature (Aly \& Amer, 2010). The green corridor can reflect the form of the city by drawing the outline of each governorate character that provides clear access to help people and transportation to get a full vision of the governorate accessibility (Hellmund \& Smith, 2006). Corridors can decline urbanization and pollutions, and beneficial for the agriculture activities, for example, protect soil loss by the wind and torrential rains (Curcic \& Durdic, 2013). Green connecting gives opportunities for citizens for pedestrians' movement with clear access and providing the highest quality of living requirements to relax, significant physical (Moseley et al., 2013). The green corridor provides Sustainable environment solutions while increasing the safety with friendly elements with nature and environment (Hunke \& Prause., 2013).

Individuals can exchange between the patches to decrease population declines isolated patches and improve the wildlife at each small habitat (Fleury \& Brown, 1997). The green network provides minimizing the health problems; attract tourism, social benefits by providing open areas for different activities, reducing the crime by offering areas for human activities (Eraghi et al., 2015).

\subsection{The Relation between Green Corridors and Environmental Sustainability}

Green areas are used for different activities for people with different ages, that a part of planning space in the cities with different types of plants, shrubs, trees and vegetation, that is comfortable, aesthetic, safety to make a social and local communicate through urban open spaces (Groenewegen et al., 2006). That is achieving sustainable urban planning by green areas through improves the air quality of life for citizens (Teimouri \& Yigitcanlar, 2018). The green corridor provides many environmental benefits in open areas, ranging from protection, supporting environment requirements and absorption of polluted gases. The green corridor reduces the energy costs which use in the adaptation by tempering temperatures in the external atmosphere (R.M et al., 2017). Green connectivity is improving the level of sustainability for the residents, that linking is protecting and improving natural resources to increase the community with the environment (Eraghi et al., 2015). Management planning for green corridor provides natural and cultural green area structures reflect the need for all residents (Pena et al., 2010). Urban green areas are an essential factor of sustainability in cities, green network planning provides all the required for the high qualities of biodiversity (Shahani, 2012). According to Mensah et al. (2017), environmental sustainability defines as a concept of reservation elements of nature environment. The quality of the green spaces will be used to identify the city, which can improve the standard of living in the city (Rostami et al., 2013). 


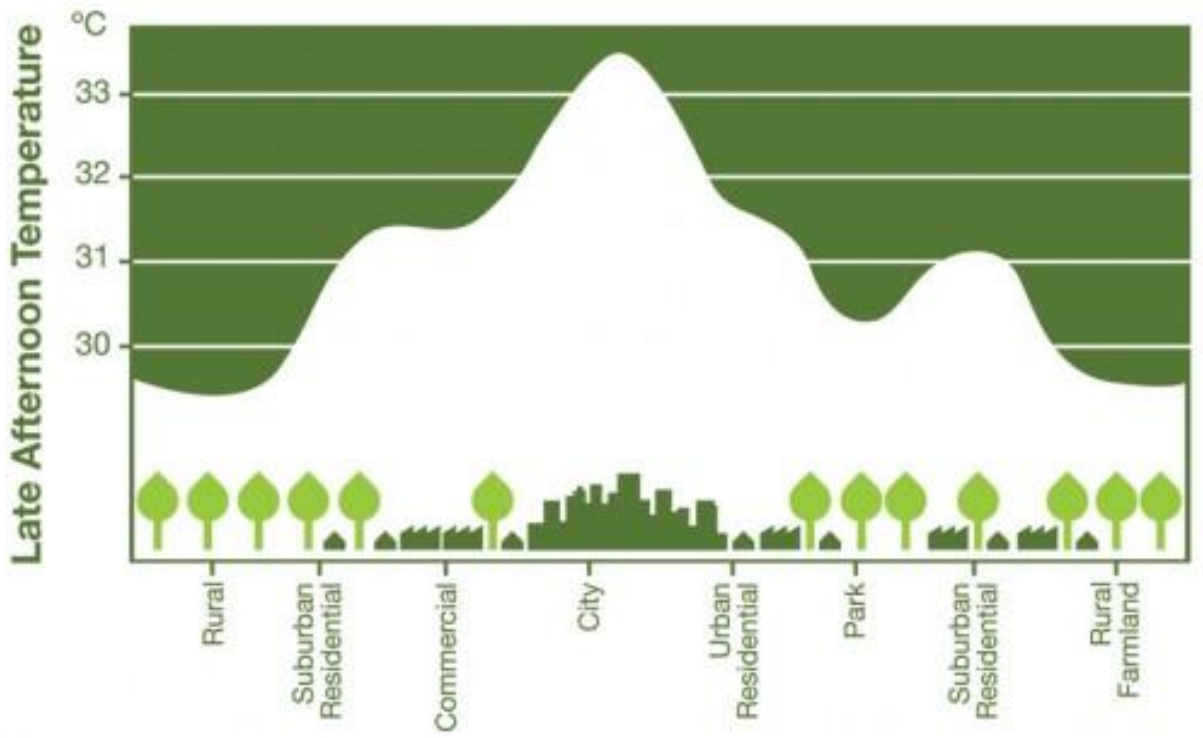

Figure 2.1: green areas affect on the temperature in a city. Source: healthyurbanhabitat.com.au

Green spaces have economic and environmental importance, providing recreational space for citizens and tourists, which lead to job opportunities within the city (Abizadeh \& Zali, 2013), See Figure 2.1.

The distribution green areas along stairs and pedestrian walkways in the center of a city that improves the quality of life living and among the residential areas. That can enhance people`s activities with a healthy and better living environment.

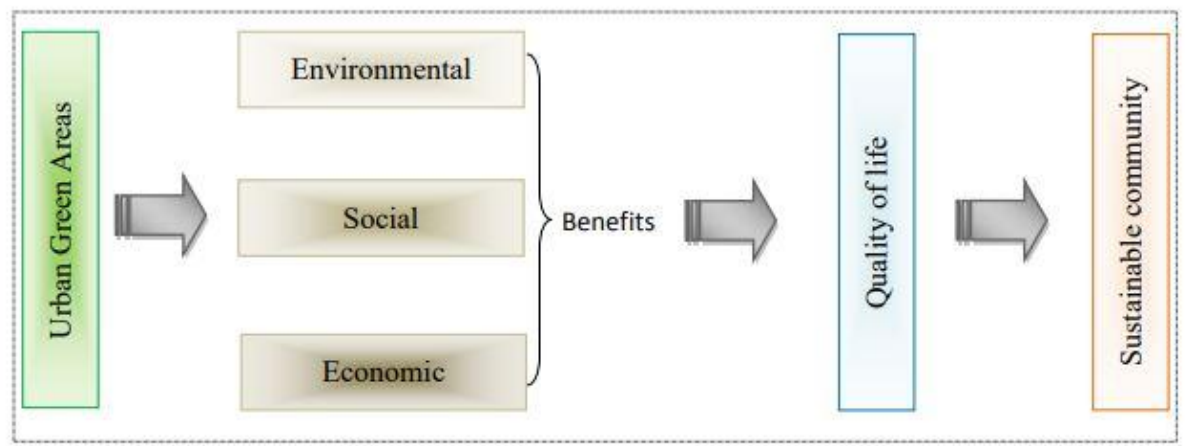

Figure2.2: The sustainable community (Elgizany, 2014)

According to Figure 2.2, urban green areas as an important factor provide social, environmental and economic benefits to achieve the community for all human activates within nature features.

\section{Aim And Objectives}

This research aims to analyze and provide a green corridor in four cities in Jordan. A green corridor is providing connectivity of different fragmented habitats. There are many benefits of designing a green corridor by supporting isolated patches. 
Some of the benefits are providing continues habitat patches for wildlife, make places more attractive for tourism, increasing air quality, providing sustainable living environment for all organisms and humans. Unfortunately, the urbanization causes loss of green spaces in general. There are many environmental and economic problems, reduction in the connectivity of wildlife which is decreasing numbers of birds. Green corridors try to solve them by providing the following objectives:

- Protecting the natural environment.

- Increasing the awareness of the local citizens to support wildlife by creating buffer zones along the green corridor.

- Reducing visual pollution by establishing a green corridor among the populated areas.

The development of forest areas in the four cities by providing integrated connectivity of green spaces least transformed by man, Green corridor creates links between the green areas of squares and playgrounds that provide all the services needed by humans in terms of visual, audio and sensory.

\section{The Research Methodology}

Urbanization growth has become represented many environmental problems as a source for visual pollution that affects negatively for human activates and ecotourism. Protected areas in Jordan are attractive places for tourism. Land-cover planning is an important factor to enhance the protected areas and forest zones in Jordan. This research aimed to create a green corridor proposal between the forest and protected areas are located in four cities in Jordan, green connectivity shows comprehensive planning of the representativeness of biogeographically areas, ecotourism and variety of vegetation in the protected areas namely, Ajloun Forest Reserve and Dibben Forest Reserve, to link them in the biodiversity regions in the Al-Salt and North. In order to meet the objectives of the thesis, the author has shown qualitative research methods under two sections. The first section concentrated on data collection from literature reviews, urban observations, maps were obtained from different ministries of each city. While the second section concentrated on the application and analyze the data from the first point according to the following spatial criteria:

- The green corridor should be closed to a wetland area to support the wildlife (Zarqa River as an example in the study area) (Aziz \& Rasidi, 2014).

- The green corridor should be closed to wildlife diversity zones as a protected area (Ajloun forest reserve and Dibben forest reserve ) and natural features (Zay forest and Alhummer)

- The green corridor should be passing different elevations gradient $(200 \mathrm{~m}-1200 \mathrm{~m})$ to provide comfortable sustainable places for visitors (Eraghi et al., 2015). The slope should be smoothed lees than 10\% and the steeper decrease in the number of green spaces (Davies et al., 2008). Green corridor reduces the sharp difference in temperature during the four seasons in Jordan $\left(31.5 \mathrm{C}^{\circ}-\right.$ $5.7 \mathrm{C}^{\circ}$ ) (Odeh et al., 2017; Freiwana \& Kadioglum, 2008).

- The green corridor should be away from highways by creating buffer zones along the path to protect the wildlife and provides safe places for visitors (Alexandre et al., 2010)

- The green corridor should be designed according to the topography and contour lines to be parallel with urbanization growth directions most of the cities in Jordan characterized by topography (Fakhouri \& Haddad, 2017). 
- The wider green corridor is better for wildlife there is no scientific data to determine a green width (Peng et al., 2017).

- The green corridor should be tried to separate the populated areas to provide open spaces for citizens.

While the second section concentrated on the application and analyze the data from the first point, by overlying maps on ArcGIS 10.0 and Google earth and according to the upper criteria to meet the objectives by providing green corridor proposal, is another method used to provide representativeness of the vegetation's locations, particularly in the Al-Salt and Amman. In addition, the study was supported by personal communications with the municipality of each city and urban observations of visiting on January - march, 2019.

Create a green path (corridor) connects vegetation and biodiversity`s region to allow the animals and birds to move freely especially from the north of the study area (Ajloun and Jerash) towards Al-salt and Amman, the green corridor will connect the mountains in Ajloun (Ajloun Forest Reserve) toward Jerash (Dibben Forest Reserve) to reach Zarqa River ( king Talal Dam ), that is the lowest district in the study area, that area is warm in the winter because it is low that provides a safe and suitable environment for animals and birds there is a low rainfall and less prone to storms and extreme winds in winter. Green corridor Allow the animals and birds to move from the protected areas through the green corridor and get the terrain natures mountain slopes, peaks, hills, rivers, and low areas. Suggested green corridor will provide access to natural green space for local residents and improve existing green spaces and lifestyle.

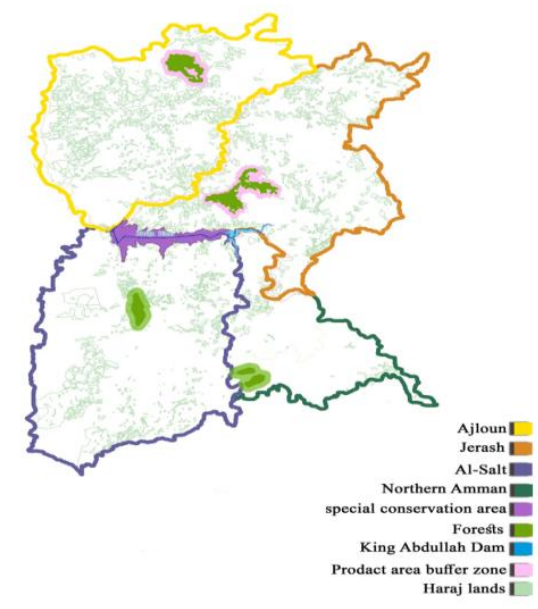

Figure 3: The rich of natural diversity, Forest Zoning and Water Resources of the study area (Ministry of Municipal Affairs, drawn by the Author, 2018). 

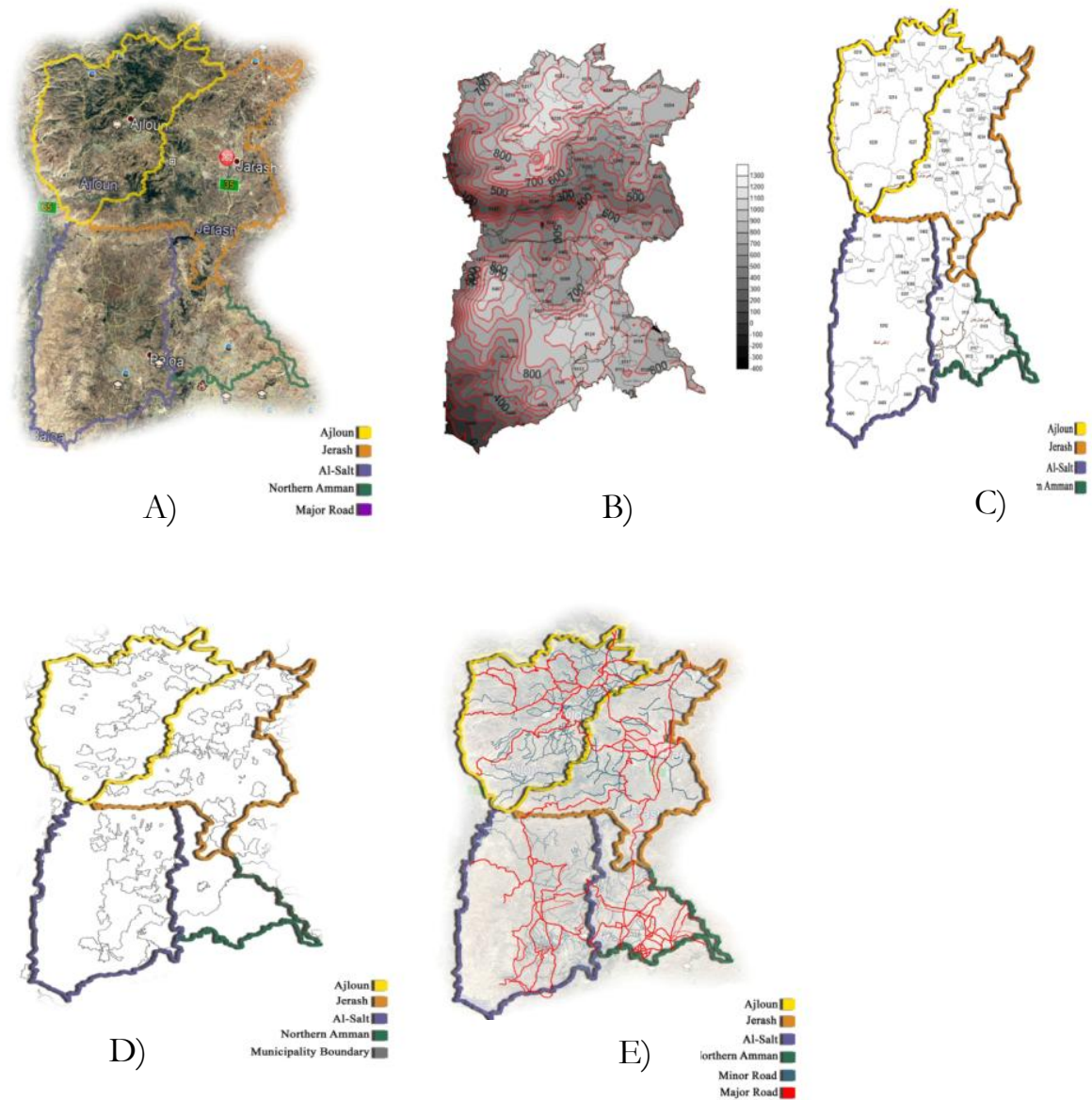

Figure 3: A) Study Area; B) Study Area Contour; C) Sector; D) Municipality boundaries; E) Roads (Ministry of Municipal Affairs, drawn by Author, 2018).

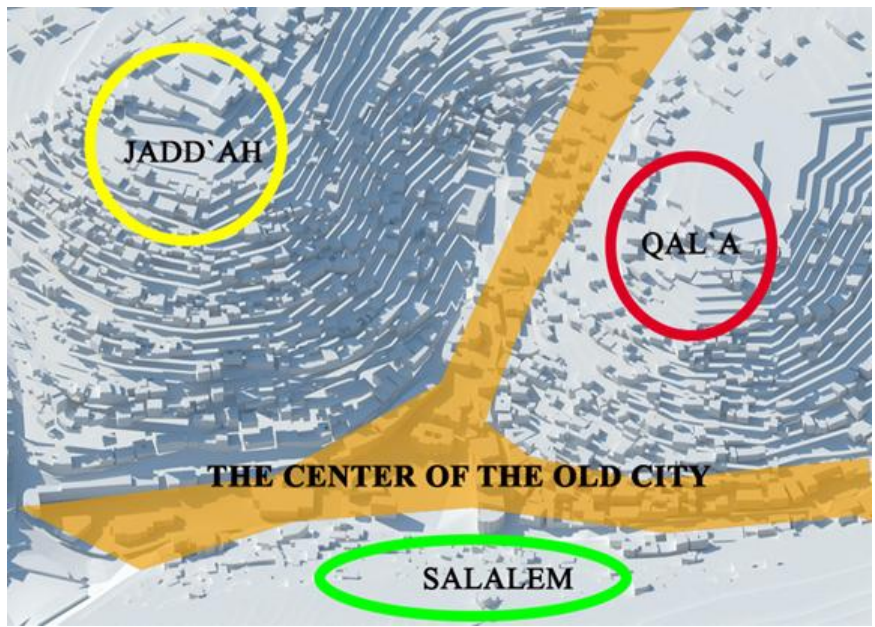

Figure 4: Al-Salt topography model with three hills to create the center of the old city (Fakhouri \& Haddad, 2017; added by Author, 2018). 
According to Figure 4, Al-Salt is characterized by the geographical sloping terrain. Three major mountains compose the ancient city of Al-Salt; one of the mountains (SALALEM) was built in modern times from the White Stone with a clear vision shows an increase in the height of buildings. Al-Salt's climate is hot in the summer and cold in the winter as a Mediterranean country (Almatarnh, 2013).

\section{Data Analysis}

Jordan located in the southwest part of Asia Continental. People from different cultures have come to this region in a continuous way; Jordan had various civilizations and nations migrations which were built on them civilizations committees at that time. As were built rooted kingdoms in various locations: Napatiens on the southern part, Ammonites in the middle, and Gileadians and Ghassanid in the north, and the expansion of the Romans, Byzantines impact then on the land of Jordan in $63 \mathrm{AD}$, the region stayed under the control of Romanian during the four hundred years, until the presence of Muslims, that end to the Byzantine existence by Arabs and Muslims who were came from the south. Still, Jordan had been a representation of Various Islamic Rules Systems (Ghraybeh, 2014).

Jordan Emirate appeared in 1921 and Prince Abdullah manages this region, and Hashemite Family ruled Jordan until this moment. The populations' citizens from different cultures have come to this region in a continuous way; Jordan had various civilizations and nations migrations, which gave Jordan its contemporary personality. In addition, an important factor gave country special socialization identical in making Jordanians like Bedouins in their Habits and traditions upon its regional site and its short distance from the south where many Bedouin Arab Tribes came from there and settled on Jordan area (Gharaybeh, 2014). 

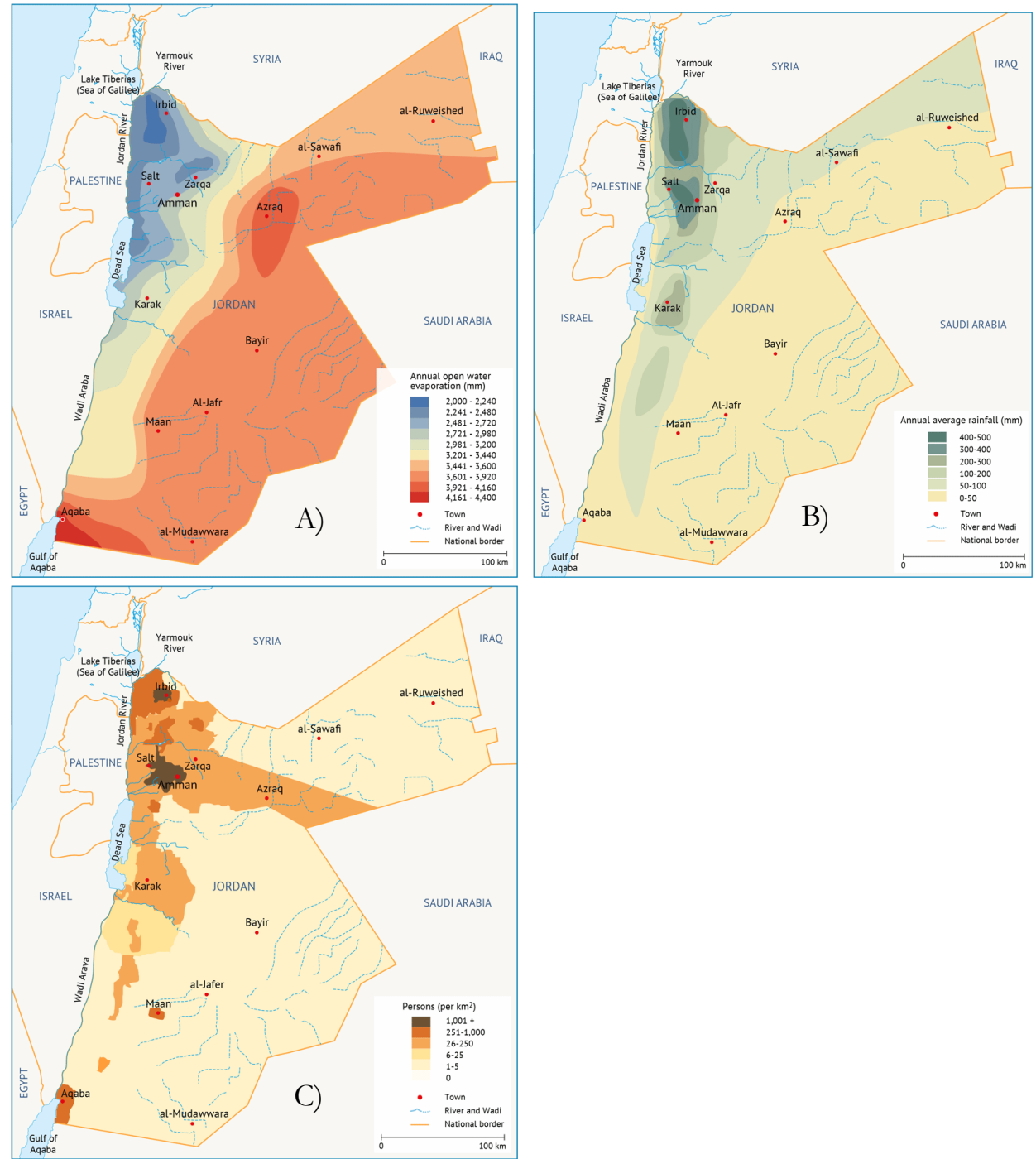

Figure 5: A) Annual open water evaporation; B) Annual average rainfall and precipitation; C) Population density Source: ww.water.fanack.com/jordan/geography-climate-population/ frank.

According to Freiwana \& Kadioglu (2008), the county of Jordan is divided into a desert Lands towards the east and Mountain Highland areas in the west according to the biogeographic nature. The huge Rift Valley Determines the eastern and western banks of the Jordan River, with more than $70 \%$ Stable Jordanian population living in that region (CIA, 2016). The Characteristics of the soil and the shortage of water resources, as well as variable rainfall, in addition, reduce the capacities and possibilities of majority land covers and other natural factors (FAO, 1992). The climate of the study area shows a Sharp difference in temperature in the two main seasons and temperature average from $31.5^{\circ} \mathrm{C}$ in the summer to $5.7^{\circ} \mathrm{C}$ in the winter. 
In Figure 5, the maps show the highest annual rainfall in the northwest of Jordan that supports wildlife and the environment diversity, designing a green corridor in this area encourages to between the isolated patches, in addition increasing the vegetation in the northwest reduces the highest annual water.

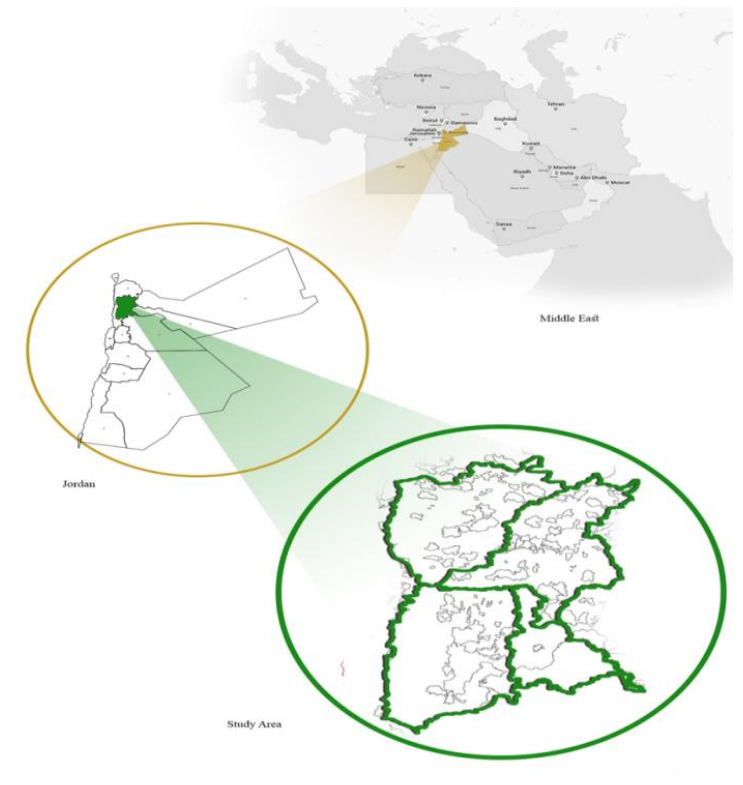

Figure 6: The Hashemite Kingdome of Jordan, Study area, MOMA; added by Author, 2018).

The location of Jordan (The Hashemite Kingdome of Jordan) in the middle east, Jordan is a Mediterranean country. The large percentage of Jordan is desert, according to Figure 6 , the green area in Jordan map is mentioned in the study area, the study area is located in four cities in Jordan in the northwest namely: Ajloun, Jerash, Al-Salt and northern Amman.

Ajloun city in the northwest region of Jordan Ajloun is located at a distance less than 80 kilometers from the capital of Jordan. It's one of the smallest Jordanian governorates. It's reaching $1200 \mathrm{~m}$ height above sea level, topography covered with diversity plants, featured weather during the whole year, unique mountains, valleys with streams, unique archaeological sites, areas for climbing and various activities. That makes Ajloun an important place for tourism at both local and regional levels. This provides a quiet and beautiful area of visitor's activities (Al-Kheder et al., 2016). Ajloun Forest Reserve (see Figure 7) is a nature reserve situated within the Ajloun Governorate. Managed by RSCN (Royal Society for Conservation of Nature). Ajloun Forest Reserve Established in 1987, the area about 12 square kilometers. There is the availability of plant diversity from trees such as trees Maple, butcher, wild olive, oak and pine (RSCN, 2018). 


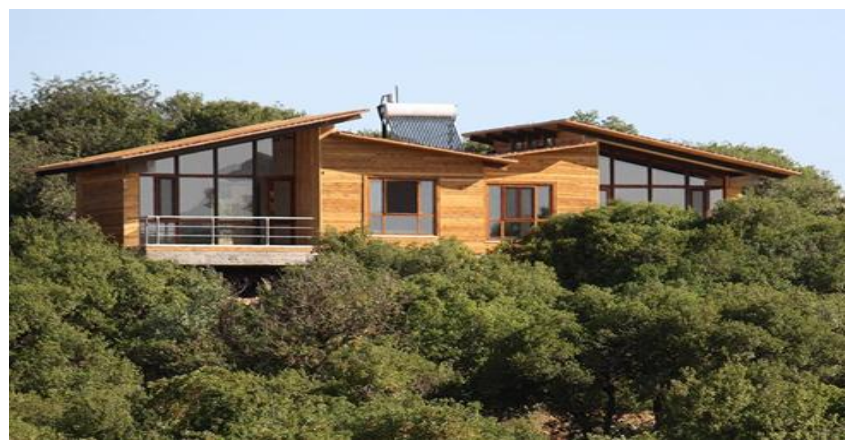

Figure 7: Ajloun Forest Reserve (RSCN, 2018).

Jerash is one of the best examples in the Middle East of Roman city; it is considered as one of the three great classical city sites in the Near East. Jerash city was a mega city during the Roman and Byzantine period and this indicated by the construction of impressive historical and archeological sites. Landscape planning in history represent the "combined works of nature and man, they are illustrative of the evolution of human societies and settlements over time". Jerash area has seen enormous development over the past 50 years, especially in the modern city of Jerash. It has many changes related to tourism development, commercial development, population growth, infrastructure, and increased utilization of natural resources". Due to the importance of the cultural landscape of Jerash and because of the rapid development in tourism and commercial sectors, there is a necessity to protect this unique cultural landscape. The cultural landscape concept belonging, outstanding, locality, meaning, and singularity of place (AlSaad, 2017). Dibben Forest Reserve Managed by the Royal Society for the Conservation of Nature, Dibben Nature Reserve Established in 2004 (see Figure 8), the area about 8.5 square kilometers, It hosts at least 17 threatened species Extinction at the local level such as the Persian squirrel. There is the availability of plant diversity from trees such as trees Maple, butcher, wild olive, oak and pine (RSCN, 2018).

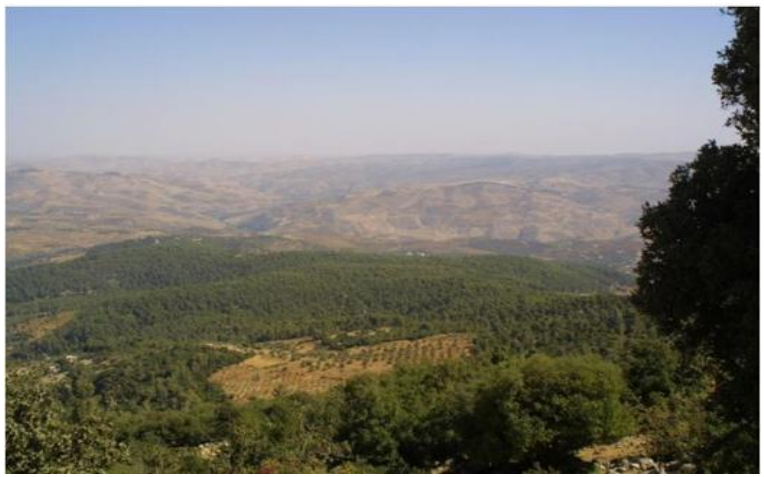

Figure 8: Dibben Nature Reserve (RSCN, 2018).

Jordan is a historical place; there are many buildings with different architectural heritage. Many different cultures, periods passed in Jordan, it is starting from the pre-historic civilization; Nabataea, Greek, Roman, Byzantine, Islamic and contemporary periods. All these periods have many cultures which shown different resources for history, tourism and, historical heritage. As-Salt city one of The historic cities full of rich architectural traditions, craft skills, design, urbanization, various arcs, key bow and decoration (Sqour 
\&Tarad, 2015). The forest zoning in Al-Salt city is presented in Zay area (see Figure 9), Zay is a village in Jordan. It is one of the most beautiful natural resorts in Jordan and a district of Al-Salt city, Zay forests famous for pine, cypress, olives, and grapes, dominated by mountainous nature and perennials trees. To the west we can see the Jordan Valley from Zay`s mountains, most of the visitors to the forests of Zay are Jordanian citizens (personal communication, January 2019).

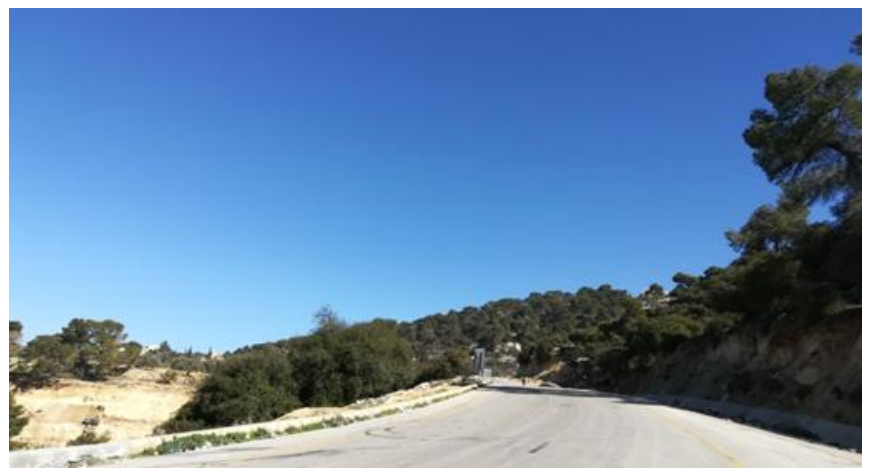

Figure 9: Zay Forest in Al-Salt city (Author, 2019)

Amman is the Capital of Jordan. Seven major mountains compose the ancient city of Amman (Raselain) there is Greater Amman Municipality located, to the west of Amman is Al-Salt where a major road (Alsarou Street) links them (Potter et al., 2008).

The topography of Amman illustrates the shape of the city and Transport network within the city so that has planned each district, the names of each district have attributed to the name of the mountain where it is located (Al-Azhari \& Al-Najjar, 2012). Alhummar forest (see Figure 10) is located to the west of the Capital of Jordan, A mountainous area filled with pine trees, that forest the King of Jordan and his family are living. Alhummar is a beautiful and quiet area with landscapes related to Al-Fuhais city, west of Balqa Governorate, and we can see Al-Salt's mountains (Personal communications, 2018).

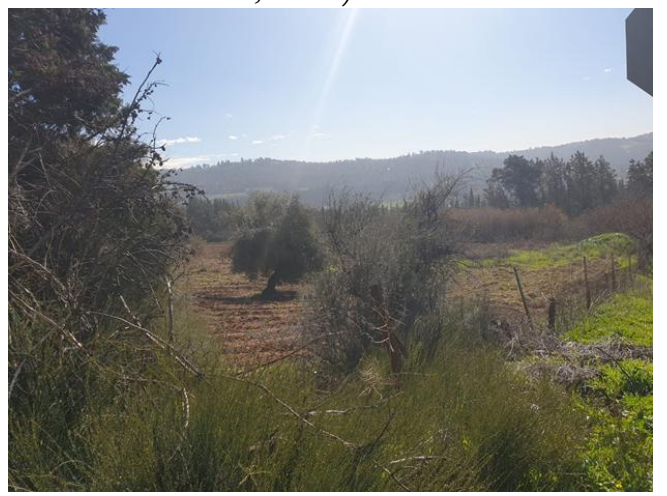

Figure 10: Alhummer Forest (Author, 2018).

\section{Corridors` connectivity proposal}

The concept in design green corridor is connecting the highest areas $(1200 \mathrm{~m}$ $1000 \mathrm{~m})$ to lower areas $(1000 \mathrm{~m}-700 \mathrm{~m})$ down to Zarqa river $(400 \mathrm{~m}-200 \mathrm{~m})$ as a water 
resource, thus obtain a suitable and gradual topographic design to enhance and facilitate. The proposal aims to adapt of the green corridor to urban areas, the establishment of green corridor network between conservation areas in Jerash and Ajloun during natural connectivity to Al-Salt and north of Amman to be a possible ecological structure of the study area. A deeper understanding of the relations between contour lines and elevations is important part of planning. Moreover, determination of the various terrains, for wildlife is also crucial during green corridor establishment issues.

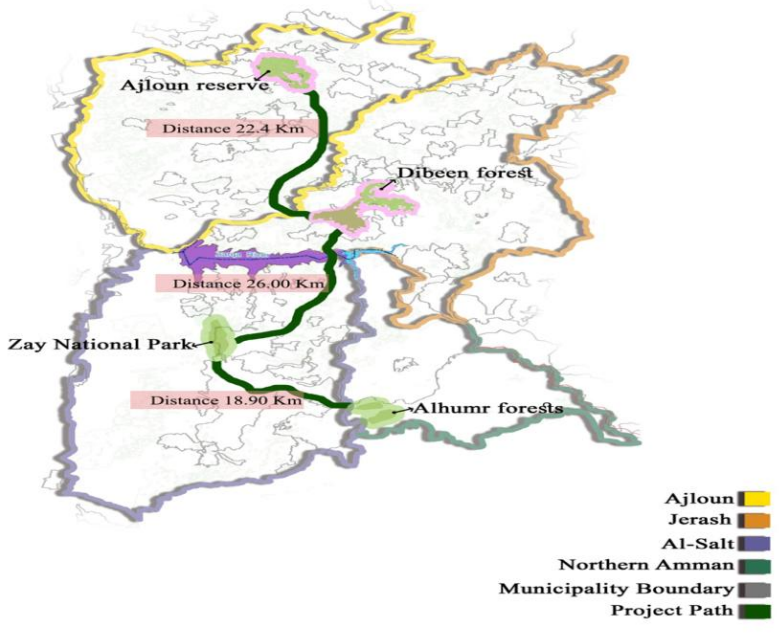

Figure 12: Green corridor path with distances (ministry of municipals affairs, 2018, drawn and added by Author, 2019).

\section{Results and Discussion}

The green corridor has designed by a deeper understanding of the relations between contour lines and biodiversity`s requirements. The green corridor provides connectivity of one habit fragment from other areas of habitats and allows an exchange of individuals between natural living elements. Conservation of the natural open areas along the green corridor that promotes biodiversity and be home to a diverse mix of habitats and wildlife and creates new green spaces for multi-functional residents and promote healthy lifestyles. The process of linking the rich green areas with protected areas of study area increases and allows breeding for many birds and animals within the varied environmental landscape. When the green path passes through the low areas (Zarqa river) it may provide a comfortable zone for wildlife`s requirements in the cold days, where is less prone to extreme winds as it represents warmer region than mountain areas. The proposal aims to adapt to the green corridor to urban areas, the establishment of green corridor network between rich diversity areas. This green corridor shows the environmental nature of the inhabitants and reduces the high temperature in the summer and moisturizes the atmosphere, which leads to expansion of local and external tourism, which improves the economic strength and increases the number of opportunities for citizens. 
Figure 13 shows the green corridor is passing different elevations gradient (200m $1200 \mathrm{~m}$ ) to provide comfortable sustainable places for visitors (Eraghi et al., 2015). The slope should be smoothed lees than $10 \%$ and the steeper decrease in the number of green spaces (Davies et al., 2008). That reduces the sharp difference in temperature during the four seasons in Jordan (31.5 $\mathrm{C}^{\circ}-5.7 \mathrm{C}^{\circ}$ ) (Odeh et al., 2017; Freiwana \& Kadioglum, 2008).

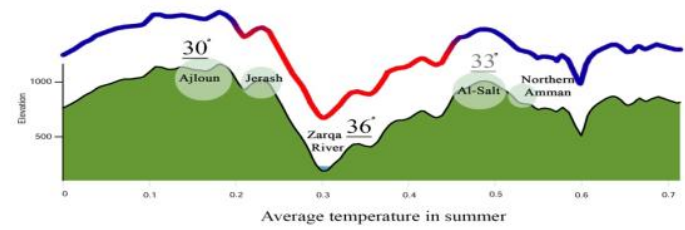

Figure 13: Average
Temperature (added by
Author, 2019).
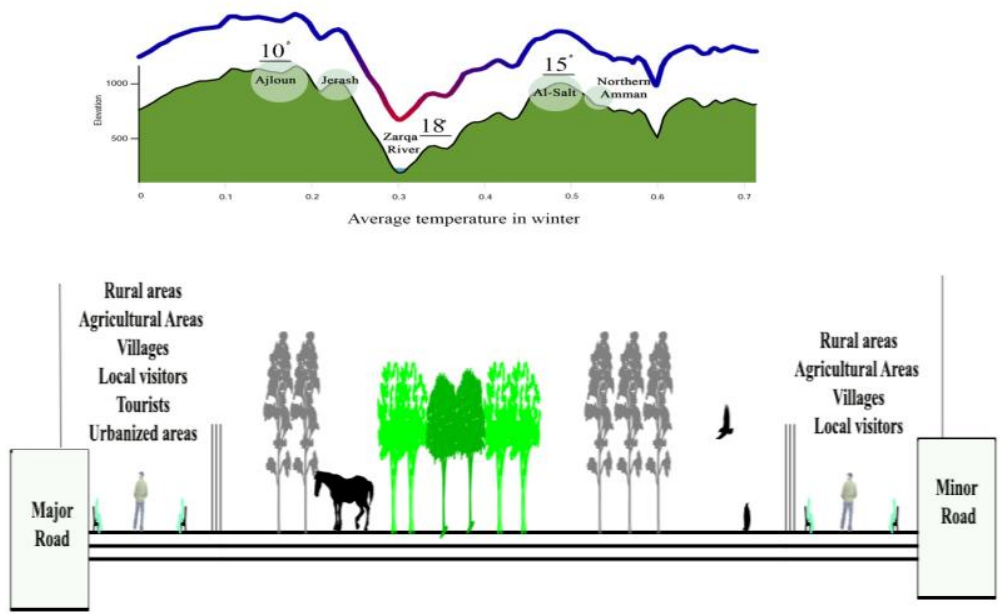

Figure 14: Detailed section views of the green corridor (Author, 2019).

The green corridor should be away from highways by creating buffer zones along the path to protect the wildlife and provides safe places for visitors (Alexandre et al., 2010). According to Figure 14, designing buffer zones along the green corridor as open spaces provide a vital area for all services needed by humans, attractive places for tourism, increase air quality, protect the natural environment, and enhance awareness of humans to protect wildlife 

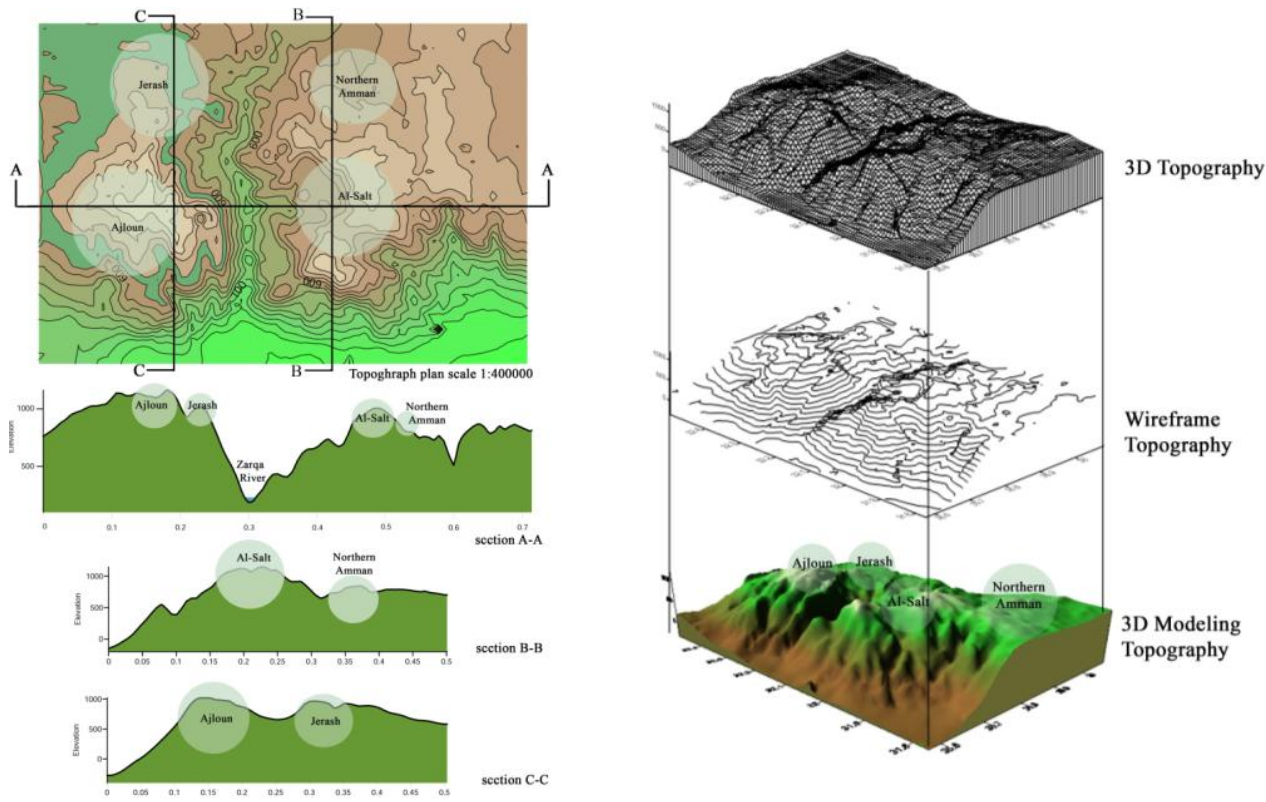

Figure 15: Section views of topography; 3D Topography (source Google Earth, added by Author, 2019).

The higher elevations have been shown a sharp difference in temperature less than lower elevation (Zhao et al., 2019). Jordan weather is dry hot and dry in summer and cold in the winter. The green corridor provides suitable places for different types of wildlife.

There is a need to increase the number of green spaces in Jordan of human activities. The problem of shortage of green areas is facing the people and where the design and urban expansion infringes on these green spaces. Especially within the city centers, there is a severe shortage of green areas within these cities. Figure 16 shows the green corridor design works to increase the green spaces around the cities and this idea separates densely populated areas. This corridor passes through mountains, peaks, hills, and valleys, the network between the protected areas and the rich diversity forest in Al-Salt and Amman allows an exchange of individuals between natural living elements. The green corridor provides an environment suitable for the residents during the winter and summer, as the passage of the green corridor in the mountain areas provides tourist areas with mild temperature in the summer. 

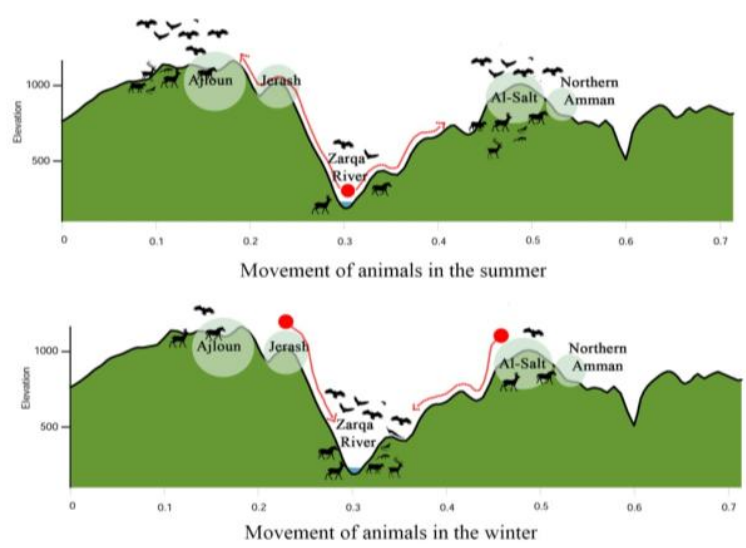

Figure 16: Movement of animals (added by Author, 2019).

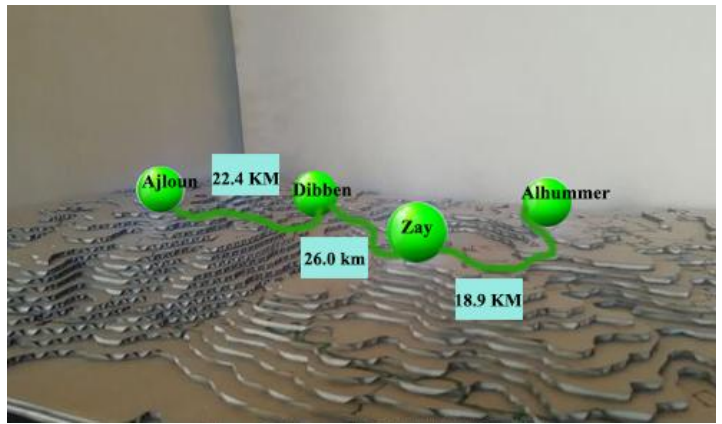

A)

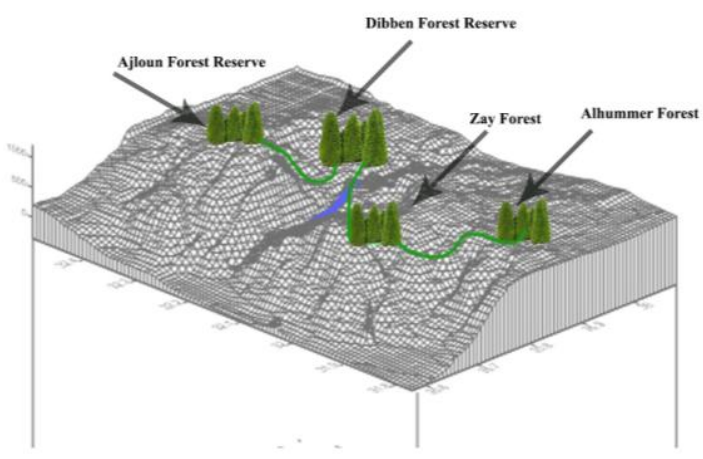

B)

Figure 17: A) Topography 3D Model, B) Green corridor with the topography of the study area (Author, 2019).

\section{Conclusion}

Planning and evaluating the advantages of corridors for biodiversity conservation is difficult, the fact that there are numerous impacts design of corridors depending on the plant's type, corridor length, and geographical location. Use of corridors changes particularly between species allows an exchange of individuals between natural living elements. The researchers and interested have been shown that the green corridors with expanded forest cover, the greater amount of natural or semi-natural habitat like a river, lake, would have greater quantities numerous of species presence. These species are represented in natural elements trees, shrubs, grass, animals, birds, in the green corridor is effective because of their requirements and developmental needs.

The green corridors offer opportunities for citizens, shelter, food, attractive places and protection which allow the biodiversity of wildlife to survive and exchange from one habitat (green space) to another. Human activities have affected the wildlife by 
reducing the humble awareness of citizens has appeared in hunting and cutting trees to heat the houses and cutting of trees to construct new commercial buildings. The framework of design green corridors has been very important for planners and decisionmakers. In the future, the government should design a green corridor to connect all cities in Jordan, a green corridor meets the needs of population inflation. The coordination of citizens and biodiversity within the same matrix needs to additionally analyze given deeper attention on the green areas.

The importance of the green corridor is to improve species richness at patch and landscape scales and can help keep up maintain ecosystem processes such as reproduction of wild animals which allows the exchange of individuals between wildlife natural living elements.

\section{References}

Abizadeh, S., \& Zali, N. (2013). Analyzing Urban Green Space Function Emphasizing Green Space Features in District 2 of Tabriz metropolis in Iran. Anuario do Instituto de Geociencias, 36, 119-127.

Al-Saad, S. (2017). Sustainable Tourism Management at Potential World Heritage Sites: Land Use Analysis by Using GIS: Case Study: Jerash Archaeological Site, Jordan. International journal of social sciences, 3, 616-634.

Al-Azhari, W., \& Al-Najjar, S. (2012). Challenges and Opportunities Presented by Amman's Land Topography on Sustainable Buildings. Third International Conference on Construction In Developing Countries, Thailand (pages 25- 37).

Alexandre, B. Crouzeilles, R \& Grelle, C. (2010). How Can We Estimate Buffer Zones of Protected Areas? A Proposal Using Biological Data. Natureza \& Conservaşão, 8, 165:170.

Al-Kheder, S., Al-Malabeh, A., \& Al-Momani, R. (2016). Spatial Analysis and Transportation System Review for Tourism Areas in Jordan: Ajloun City as a Case Study. Jordan Journal of Civil Engineering, 10, 501-514.

Almatarneh, R. (2013). Sustainability lessons learned from traditional architecture: a case study of the old city of As-Salt, Jordan. Journal of Environment Science, Toxicology and Food Technology, 5, 100 - 109.

Aly, S., \& Amer, M. (2010).Green Corridor as a response for nature: greening Alexandria city by creating a green infrastructure network. Design And Nature, 138, 101-117.

Arpentieva, M. (2018). Ecology and Nature Conservation in Russia. Natural Resources Conservation and Research, $1,1-15$.

CIA, Central Intelligence Agency. The World Factbook-Jordan. Central Intelligence Agency. From ( https://www.cia.gov/library/publications/the- Retrieved 28 August, 2016).

Curcic, N., \& Durdic, S. (2013).The actual relevance of ecological corridors in nature conservation. Journal of The Geographical Institute. 63, 21-34.

DOS, (2010). Department of Statistics: Hashemite Kingdom of Jordan. Jordan in figures. Amman, Jordan.

Elgizawy, E. (2014). The Significance of Urban Green Areas for the Sustainable Community. Conference Paper, 1-14.

Eraghi, S., Meschi, M., \& Gholampour, S. (2015). Styding the Relationship Between Urban Green Corridors and Sustainable Urban Landscape. International Journal of Science, Technology and Society, 3, 36-40.

Fakhouri, L., \& Haddad, N. (2017). Aspects of The Architectural and Urban Heritage: From Registers to Conservation For Adaptive and Modern Use at The Historic Cores of Salt and Irbid, Jordan. International Journal of Architectural Research, 11, 190-218.

FAO, Food and Agriculture Organisation of the United Nations. (1992). Inventory and assessment of land resources for near east and Africa Region. Retrieved from http://www.fao.org/home/en/

Fleury, A., \& Brown, R. (1997). A framework for the design of wildlife conservation corridors with specific application to southwestern Ontario. An International Journal of Landscape Ecology, 37, 163-186.

Freiwana, M., \& Kadioglu, M. (2008). Spatial and temporal analysis of climatological data in Jordan. International Journal of Climatology, 28, 521-535. 
GAM, (2018). Greater Amman Municipality. Amman, Jordan.

Gharaybeh, K. (2014). General Socio-Demographic Characteristics of the Jordanian Society: A Study in Social Geography. Research on Humanities and Social Sciences, 4, 1-10.

Groenewegen, P., van den Berg, A., de Vries, S., \& Verheij, R. (2006). Vitamin G: effects of green space on health, well-being, and social safety. BMC Public Health, 6, 1-9.

Haddad, N., Al-Khader, S., \& Fakhoury, L. (2013). Al Mujib Reserve in Jordan: Towards an Assessment for Sustainable Ecotourism Management Plan Utilizing Spatial Documentation. Natural Recourses and Conservation, 1, 65-76.

Hellmund, P., \& Smith, D. (2006). Designing Greenways, Sustainable landscape for nature and people, Island Press: Washington, 215, 127-132.

Hilty, J., Lidicker, W., \& Merenlender, A. (2006). Corridor Ecology: The science and practice of linking landscapes for biodiversity conservation. Island Press: Washington (page 114).

Horskins, K., Mather, P., \& Wilson, J. (2005).Corridors and connectivity: when use and function do not equate, Landscape Ecology, 21, 641-655.

-Hunke, K., \& Prause, G. (2013). Management of Green Corridor Performance. Estonia, Transport and Telecommunication, 14, 292-299.

JaberJ.O., \& Probert, S.D. (2001). Energy demand, poverty and the urban environment in Jordan. Applied Energy, 68, 119-134.

Makhamreha, Z., \& Almanasyeha, N. (2011). Analyzing the state and pattern of urban growth and city planning in Amman using satellite images and GIS. European journal of Social sciences, 24, 252-264.

Mensah, C., Antwi, K., Eshun, J., \& Baidoo, P. (2017). Towards sustainability: Overcoming the physical barriers to urban green spaces in Kumasi, Ghana. Ghana Journal of Geography, 9, 125-150.

MOA, (2018).The Ministry of Agriculture. Amman, Jordan.

MOE, (2018). The Ministry of Environment. Amman, Jordan.

MOMA, (2018). The Ministry of Municipality Affairs. Amman, Jordan.

Moseley, D., Marzano, M., Chetcuti, J., \& Watts, K. (2013).Green networks for people: Applications of a functional approach to support the planning and management of greenspace, Landscape and Urban Planning, 116, 1-12.

Nadubisi, F., DeMeo, T., \& Ditto, N. (1995). Environmentally sensitive areas: a template for developing greenways corridors. Landscape and Urban Planning, 33, 159-177.

NARC, (2018).National Agricultural Research Center. Amman, Jordan.

Odeh, T., Boulad, N., Abed, O., Abu Yahya, A., Khries, N., \& Abu-Jaber, N. (2017). The Influence of Geology on Landscape Typology in Jordan: Theoretical Understanding and Planning Implications. Journal Land, 6, 1:13.

Pena, S., Abreu, M., Tales, R., \& Espirito-Santo, M. (2010). A methodology for creating greenways through multidisciplinary sustainable landscape planning. Journal of Environmental Management, 91, 970-983.

Peng, J., Zhao, H., \& Liu, Y. (2017). Urban ecological corridors construction: A review. Acta Ecologica Sinica, 37, 23:30.

Potter, R., Darmame, K., Barham, N., \& Nortcliff, S. (2007). "Ever-growing Amman", Jordan: Urban expansion, social polarization and contemporary urban planning issues, 182, 81-92.

Ratih, Y., \& Fabrinato, J. (2016). Biodiversity as part of urban green network system planning case study: Pontianak City. Procedia-Social and Behavioral Sciences, 227, 583-586.

R.M, K., Kuchi, V., \& Salma, Z. (2017). The Role of Green Space for Sustainable Landscape Development in Urban Areas. International Archive of Applied Sciences and Technology, 8, 76-79.

Rostmai, R., Lamit, H., Khoshnava., \& Rostami, R. (2013). Urban Green Spaces and City Sustainability. Asian Journal of Microbiology, Biotechnology and Environmental Sciences, 15, 441-446.

RSCN, (2018). Royal Society for the Conservation of Nature. Amman, Jordan.

Saleh, b., \& Al Rawashdeh, S. (2007). Study of Urban Expansion in Jordanian Cities Using GIS and Remote Sensing. International Journal of Applied Science and Engineering. Jorda, 5, 41- 52.

Shahani, F. (2012). The Role of Green Way in the Achievement of Urban Sustainable Development (District 3 of Tehran as a Case Study).World Applied Sciences Journal, 19, 1514-1522.

Sqour, S., \& Tarad, M. (2015). A Jordanian model in conservation of architectural heritage, Case Study Dar As Saraya Government Building, Madaba, Jordan ( Retrieved from https://marhi.ru/AMIT/2015/1kvart15/sqour/sqour.pdf). 
Teimouri, R., \& Yigitcanlar, T. (2018). An approach towards effective ecological planning: Quantitative analysis of urban green space characteristics. Global Journal of Environmental Science and Management, 4, 195-206.

Tukan, J. (1995). Architectural character for Amman city. Proceeding of Amman Conference, A Reality and Ambitions, Greater Amman Municipality, May 1995.

Walker, R., \& Craighead, L. (1997). Analyzing Wildlife Movement Corridors in Montana Using GIS, Conference paper.

Zhao, W., He, J., Wu, Y., Xiaong, D., Wen, F., \& Li, A. (2019). An Analysis of Land Surface Temperature Trends in the Central Himalayan Region Based on MODIS Products. Remote Sensing, 11, 1-19. 